\title{
Penentuan Saluran Pemasaran terhadap Tingkat Harga pada Rantai Pasok Kedelai (Glycine max (L.) Merr.) di Kabupaten Grobogan Provinsi Jawa Tengah
}

\author{
Determination of Market Chain on the Level of Prices of Soybean Supply Chain (Glycine max (L.) Merr.) \\ in Grobogan, Central Java Province \\ Novita Erma Kristanti*, Iqbal Saimima Almuntaha \\ ${ }^{1}$ Departemen Teknologi Industri Pertanian, Fakultas Teknologi Pertanian, Universitas Gadjah Mada, \\ Jl. Flora No. 1, Bulaksumur, Yogyakarta 55281, Indonesia \\ Email: erma@tip-ugm.org
}

Submisi: 22 Desember 2016; Penerimaan: 18 Juli 2017

\begin{abstract}
ABSTRAK
Penelitian ini bertujuan untuk melakukan penentuan perilaku pasar terhadap tingkat harga kedelai di wilayah Grobogan. Dalam penentuan perilaku pasar tersebut perlu diketahui nilai tingkat harga dengan perhitungan elastisitas permintaan terkait harga dengan aktivitas supply dan demand kedelai dan penentuan rantai pasok kedelai yang dinilai paling efisien. Metode pengumpulan data dilakukan dengan teknik convenience dan snowball sampling melalui indepth interview kepada pelaku rantai pasok (supply chain) dan dinas pertanian tanaman pangan dan hortikultura, Kabupaten Grobogan. Dengan menghitung nilai elastisitas transmisi harga (Et) pada saluran pemasaran kedelai dan nilai elastisitas transmisi harga diperoleh nilai tertinggi pada saluran pemasaran 4 dengan nilai 2,509. Konsentrasi rasio rata-rata pengepul 0,8501, dan tier pedagang 0,94554 . Nilai tersebut menunjukkan bahwa perilaku pasar yang paling efektif menggunakan saluran pemasaran yang paling efisien dengan permintaan yang efektif yaitu saluran pemasaran 4 yang terdiri dari petani, kelompok tani, serta pengrajin tahu dan tempe.
\end{abstract}

Kata kunci: Permintaan; elastisitas; saluran pemasaran; harga; rantai pasok kedelai

\begin{abstract}
This research was aimed to determine the affect of market behavior on a price of soybean in Grobogan. In order to determine the market behavior, demand elasticity related to soybean price and its supply demand activity as well as selections the most efficient supply chain were needed. The method used for data collection were convenience and snowball sampling by indepth interview with supply chain actor and department of agriculture of food crops and holticulture, Grobogan district. The result of the calculation of the price transmission elasticity values obtained the highest value on channel 4 with the marketing value of 2,509. The average of concentration ratio of the middleman was 0,8501 , and tier was 0,94554 merchant. These values indicated that the most efficient marketing channel with an effective demand is marketing channel 4 consist of farmers, farmers group, as well as tofu and tempe industries.
\end{abstract}

Keywords: Demand; elasticity; market channel; price; soybean supply chain 


\section{PENDAHULUAN}

Dalam kebijakan umum ketahanan pangan tahun 2014 diketahui bahwa sektor pangan perlu ditingkatkan, baik dalam jumlah, keragaman dan mutu untuk memenuhi kebutuhan pangan penduduk yang terdiri dari sektor pertanian, hortikultura, peternakan, perkebunan, kehutanan dan kelautan. Selain itu, pemenuhan kebutuhan bahan pangan penduduk Indonesia tidak hanya difokuskan pada lahan sawah, tetapi juga diarahkan pada sumber karbohidrat non beras serta pengembangan produksi komoditas sumber protein, seperti kacang-kacangan, daging sapi, ayam, telur, ikan, susu, sayur dan buah. Kedelai (Glicine max (L.) Merr.) merupakan salah satu komoditas pangan nabati yang dikenal sebagai bahan baku olahan pangan yang merupakan sumber protein menyehatkan dengan harga terjangkau. Pada umumnya kedelai dikonsumsi dalam bentuk pangan olahan, antara lain tahu, tempe, tauco, oncom, kecap, susu kedelai, dan berbagai bentuk makanan ringan. Sifat multiguna kedelai menjadikan kedelai semakin diminati konsumen dan menjadi kebutuhan strategis di Indonesia.

Pada penelitian Nurhayat (2014) diketahui bahwa struktur biaya produksi kedelai jauh lebih besar dibandingkan nilai produksi yang dihasilkan per tahun dari setiap hektar lahan kedelai dengan b iaya produksi tanam kedelai sebesar Rp 9,1 juta/hektar/tahun sedangkan petani hanya mampu memberikan hasil produksi kedelai sebesar Rp 9 juta/hektar/ tahun. Pada penelitian pendahuluan dilakukan perhitungan struktur biaya logistik kedelai pada wilayah Kabupaten Grobogan dan diperoleh hasil bahwa biaya yang paling dominan untuk penanganan bahan sebesar 77,73\% dengan persentase paling besar pada komponen on farm cost atau biaya produksi sebesar $62,6 \%$, oleh sebab itu diperlukan upaya pengelolaan persediaan kedelai secara optimal pada setiap tier dalam rantai pasok kedelai karena harga kedelai di tingkat petani masih fluktuatif. Berdasarkan hasil wawancara pada petani di Wilayah Grobogan diketahui bahwa dalam tata niaga kedelai melibatkan banyak pelaku rantai pasok dengan permasalahan utama yang berkaitan dengan harga cepat berubah-ubah, lemahnya pengawasan terhadap harga yang beredar dan belum adanya jaminan harga di pasar secara konsisten (Data Primer, 2016). Peran pemerintah sebagai pendamping petani masih belum optimal, hal ini dapat dilihat dari belum adanya solusi terkait kebijakan penetapan harga. Dalam kenyataan di lapangan, dapat ditemui bahwa harga yang beredar tidak seimbang dengan harga yang ditetapkan pemerintah melalui HPP (Harga Pokok Penjualan), hal ini juga dapat berdampak pada volume kedelai yang beredar di wilayah tersebut, baik dilihat dari sisi penjualan dan permintaannya serta ketersediaan yang tidak merata pada tiap kecamatan di kabupaten Grobogan. Dalam suatu perencanaan rantai pasok dapat dikaitkan dengan terbentuknya model dinamis yang dipengaruhi antara lain faktor produksi, nilai investasi, dan faktor alokasi sumber daya, baik sumber daya manusia (petani) maupun pemilik lahan (Femenia dan Gohin, 2011).

Asosiasi Petani Kacang Kedelai Indonesia (APKKI) pada bulan Maret tahun 2014 menyampaikan bahwa harga kedelai impor akan terus naik dengan asumsi jika persediaan kedelai impor terus berkurang sehingga diharapkan kondisi pasar kedelai saat ini kurang baik bagi ketahanan pangan Indonesia karena ketergantungan terhadap kedelai impor sudah mencapai 60\% (Bappebti, 2014). Kabupaten Grobogan merupakan salah satu kabupaten dengan tingkat produksi kedelai tertinggi di Jawa Tengah, di mana propinsi ini menjadi kedua tertinggi produksi kedelai setelah Jawa Timur. Di Kabupaten Grobogan ini juga memiliki varietas grobogan yang memiliki potensi produksi hingga 3,40 ton/ha (BPS, 2014)

Harga Patokan Petani (HPP) kedelai yang dinilai cukup rendah tidak dapat menjamin petani untuk mendapatkan untung sedangkan harga kedelai impor jauh lebih murah. Harga jual kedelai lokal yang rendah ini tidak menarik untuk petani sehingga petani enggan untuk menanam kedelai. Keengganan petani untuk menanam kedelai ini tentu dapat mempengaruhi ketersediaan kedelai di pasaran. Produksi kedelai nasional yang tidak dapat lagi memenuhi kebutuhan konsumsi dalam negeri, mengharuskan pemerintah melakukan impor kedelai. Pada tahun 2013, pemerintah Indonesia sudah melakukan impor kedelai sebanyak 1,6 juta ton dari Amerika Serikat (Pusdatin, 2013b). Hal ini menyebabkan harga kedelai impor yang lebih murah dibandingkan dengan harga kedelai lokal. Tidak adanya proteksi harga terhadap kedelai lokal ini menyebabkan pengrajin olahan kedelai lebih memilih kedelai impor dengan harga yang lebih murah. Fluktuasi harga kedelai lokal dan impor ini tentu akan memberikan pengaruh yang besar kepada permintaan dari konsumen kedelai. Keunggulan kedelai lokal dari sisi kualitas dan kemanan pangan lebih baik dibandingkan kedelai impor sehingga peningkatan produksi untuk pemenuhan bagi konsumen perlu terus ditingkatkan (Kristanti dan Guritno, 2016). Permintaan dari pengrajin olahan kedelai sebagai konsumen akhir ini apabila tidak ditanggapi secara cepat oleh tier sebelumnya tentu akan membuat ketidakakuratan informasi supply-demand pada suatu sistem rantai pasoknya. Kelemahan pada aliran informasi dan koordinasi tersebut seringkali menimbulkan distorsi informasi yang tentunya juga dipengaruhi oleh elastisitas harga.

Fluktuasi ataupun ketidakpastian permintaan terkait harga kedelai setelah panen beserta infrastruktur penunjang seperti peralatan yang masih kurang memadai menyebabkan hasil panen dari komoditas kedelai ini menjadi kurang 
optimal sehingga hal ini akan berdampak kepada daya serap lahan, produktivitas, dan yang terpenting adalah pemenuhan antara supply dan demand di pasar. Hal yang menjadi masalah lainnya yaitu gangguan hama dan penyakit yang menyebabkan minat petani berkurang sehingga produktivitas lahan menurun dalam memenuhi fluktuasi permintaan yang terjadi di pasaran. Nilai elastisitas permintaan terkait harga secara teoritis dipengaruhi oleh faktor perubahan jumlah volume permintaan dan juga perubahan harga yang berlaku di pasaran. Kondisi tata niaga kedelai di Indonesia yang pemasarannya masih belum terdistribusi dengan baik menyebabkan ketimpangan harga dan volume di tiap-tiap daerah yang menunjukkan saluran pemasaran yang kurang efisien dan permintaan yang kurang efektif. Oleh karena itu, melalui penelitian ini yang dilakukan di Kabupaten Grobogan dapat dijadikan template sistem tata niaga yang baik agar dapat digunakan pada daerah lainnya. Adapun penelitian ini bertujuan untuk mengukur elastisitas permintaan terkait harga dengan aktivitas supply dan demand-nya dan menentukan jalur rantai pasok kedelai yang paling efisien.

\section{METODE PENELITIAN}

\section{Identifikasi Market dan Tier dalam Supply Chain}

Objek dan wilayah dalam penelitian ini adalah rantai pasok kedelai kuning Grobogan, Jawa Tengah. Penentuan wilayah ini berdasarkan faktor keberadaan sentra komoditas kedelai yang paling besar di Jawa Tengah, yang menjadi percontohan bagi sentra-sentra kedelai yang lainnya secara nasional (BPS, 2014). Identifikasi ini dilakukan dengan melakukan penelusuran rantai pasok dan pencarian informasi dari petani hingga pedagang serta pencarian informasi aktivitas logistik yang diterangkan oleh Dinas Pertanian Tanaman Pangan dan Hortikultura mengenai tata niaga kedelai.

\section{Data}

Jenis data terdiri dari data primer dan data sekunder. Adapun pengumpulan data primer melalui proses wawancara langsung dengan Dinas Tanaman Hortikultura, Dinas Pertanian Jawa Tengah, Pelaku Rantai Pasok, dan KOPTI Industri Tahu dan Tempe. Data yang digunakan dalam penelitian ini meliputi data harga pembelian dan penjualan pada tier petani hingga ke penjual, data time series produksi kedelai tahun 2010-2014, data pemesanan pada tier pengepul dan pedagang, data permintaan dan data penjualan pada beberapa tier dalam rantai pasok kedelai, serta data struktur biaya pada aktivitas-aktivitas logistik pada beberapa tier dalam rantai pasok. Data sekunder diperoleh dari data permintaan dan penawaran dari Badan Pusat Statistik, data laporan tahunan Dinas Tanaman Pangan dan Hortikultura, dan data persediaan kedelai di tingkat pelaku rantai pasok.

\section{Nilai Elastisitas Permintaan}

Beberapa faktor dapat mempengaruhi elastisitas permintaan terkait harga, diantaranya kemampuan produk yang menggantikannya, pentingnya barang, waktu untuk keputusan, durasi produk, dan jangkauan penggunaan (Fibich dkk., 2005). Dasar penggunaan rumus elastisitas yang berkaitan dengan pengaruh perubahan harga terhadap jumlah barang yang diminta atau yang ditawarkan. Dengan kata lain, elastisitas adalah tingkat kepekaan (perubahan) suatu gejala ekonomi terhadap perubahan gejala ekonomi yang lain. Elastisitas terbagi dalam tiga macam, (1) elastisitas harga (price elasticity) yaitu persentase perubahan jumlah barang yang diminta atau yang ditawarkan, yang disebabkan oleh persentase perubahan harga barang tersebut, (2) elastisitas silang (cross elasticity) adalah persentase perubahan jumlah barang $\mathrm{x}$ yang diminta, yang disebabkan oleh persentase perubahan harga barang lain (y), dan (3) elastisitas pendapatan (income elasticity) yaitu persentase perubahan permintaan akan suatu barang yang diakibatkan oleh persentase perubahan pendapatan (income) riil konsumen.

Elastisitas permintaan dihitung dengan membagi presentase perubahan volume terhadap persentase perubahan harga yang menyebabkannya, yang dapat dihitung sesuai Persamaan 1 (Petroff, 2012).

Elastisitas permintaan terkait harga $=\frac{d Q / Q}{d P / P}$

Dimana Q adalah kuantitas permintaan mula-mula, dQ adalah perubahan dalam kuantitas permintaan yang dipengaruhi oleh perubahan dari harga $\mathrm{dP}$ dan $\mathrm{P}$ adalah harga mula-mula. Pengolahan data yang dilakukan adalah dengan menghitung besar nilai elastisitas yang akan dihitung melalui Persamaan 2 dan 3.

$$
\begin{aligned}
& \mathrm{E}_{\mathrm{s} / \mathrm{d}}=\frac{\Delta P}{\Delta Q} x \frac{P}{Q} \\
& \text { atau } \mathrm{E}_{\mathrm{s} / \mathrm{d}}=\frac{\% \Delta Q}{\% \Delta P}
\end{aligned}
$$

Keterangan:

Es $/ \mathrm{d}=$ Elastisitas penawaran atau permintaan

$\Delta \quad=$ Perubahan harga barang

$\Delta \mathrm{Q}=$ Perubahan jumlah penawaran atau permintaan

$\mathrm{P} \quad=$ Harga barang mula-mula

$\mathrm{Q} \quad=$ Jumlah penawaran atau permintaan mula-mula

Elastisitas permintaan terkait harga adalah seberapa besar persentase perubahan kuantitas permintaan sebagai hasilnya perubahan tiap 1 persen didefinisikan pada Persamaan 4.

$\varepsilon=\frac{d Q / Q}{d P / P}=\frac{d Q . P}{d P \cdot Q}$

Dimana $\mathrm{p}$ adalah harga dan $\mathrm{q}$ adalah permintaan pasar. 
Setelah dilakukan perhitungan elastisitas harga pada beberapa tier dapat diketahui pada tier manakah yang memiliki indeks elastisitas terbesar, selain itu juga dapat dianalisis penyebabnya. Sedangkan untuk perhitungan analisis sensitivitas diperoleh pada bagian tier yang memiliki sensitivitas yang tinggi maupun rendah sesuai dengan nilainya, sehingga dapat dianalisis juga penyebabnya dan dapat dilakukan strategi penentuan harga yang tepat.

\section{HASIL DAN PEMBAHASAN}

\section{Identifikasi Pelaku Rantai Pasok Kedelai}

Pendekatan sistem merupakan pendekatan terpadu yang memandang suatu persoalan sebagai suatu sistem dimana permasalahan kompleks dan bersifat antar disiplin (Simatupang, 1995). Dalam sistem rantai pasok kedelai melibatkan beberapa pelaku sistem yang bertujuan melakukan proses distribusi kedelai dari petani sampai pada konsumen. Pelaku sistem rantai pasok kedelai terdiri dari petani, pengepul, pedagang besar, koperasi industri tahu tempe indonesia (KOPTI), industri tahu dan tempe, dan pedagang pengecer. Identifikasi sistem rantai pasok kedelai menggunakan pendekatan sistem dengan tahapan seperti Gambar 1. Secara garis besar pelaku usaha tata niaga kedelai di Kabupaten Grobogan dibagi menjadi beberapa peran yaitu petani, pengepul, KOPTI, pedagang besar, pengrajin tahu/ tempe, dan pedagang kecil. Alur rantai pasok Kabupaten Grobogan digambarkan dalam 7 skema.

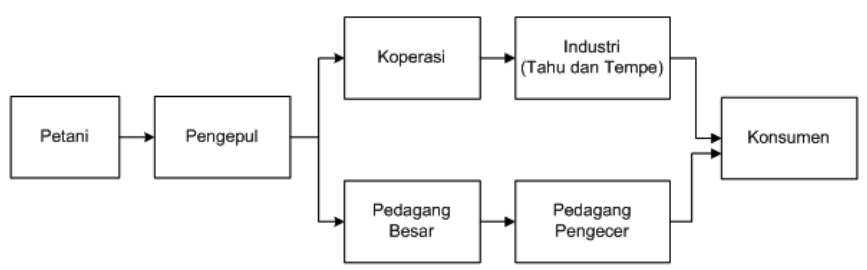

Gambar 1. Supply chain kedelai secara umum di Kabupaten Grobogan

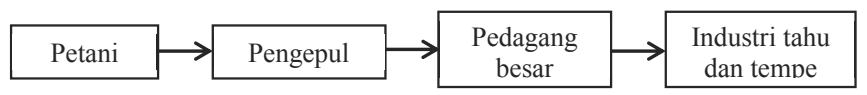

Gambar 2. Skema 1 alur supply chain kedelai

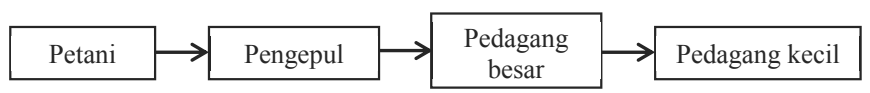

Gambar 3. Skema 2 alur supply chain kedelai

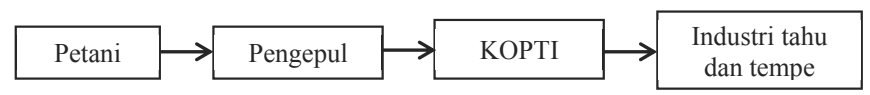

Gambar 4. Skema 3 alur supply chain kedelai
Pada Gambar 2, petani yang diambil sebagai responden adalah seseorang yang pekerjaan utamanya sebagai petani kedelai di kecamatan Pulokulon dan kecamatan Purwodadi. Petani di dua kecamatan ini mengelola lahan 0,25-1 Ha dengan kapasitas produksi berkisar 400-1.000 kg. Hasil produksi kedelai nantinya akan sampai ke pengepul dengan dua cara. Pertama, petani akan mengantarkan hasil panennya ke tempat pengepul, dan yang kedua pengepul akan mengambil hasil panen petani langsung ke lahan saat panen. Untuk cara yang kedua dilakukan pengepul karena adanya banyak saingan sebagai sesama pengepul dalam satu wilayah yang telah memiliki langganan tetap dari petani.

Gambar 3 menunjukkan bahwa saat mendekati masa panen, pengepul membeli kedelai dari petani dalam jumlah tertentu. Petani mengantarkan kedelai hasil panenannya ke pengepul yang berada disekitar wilayahnya atau biasanya masih dalam satu kecamatan. Dari pengepul lalu kedelai dijual kepada pedagang besar. Pedagang besar berperan dalam mengumpulkan kedelai dalam jumlah yang besar untuk nantinya dijual kepada industri olahan pangan kedelai sebagai konsumsinya dan juga kepada pengecer atau pedagang kecil dengan kuantitas yang lebih kecil. Pada skema 2, kedelai dari pedagang besar dikirim ke pedagang kecil (ecer). Pedagang kecil membeli kedelai dari pedagang besar dengan tujuan untuk memenuhi kuantitas penjualannya. Kedelai ini akan dijual dengan kemasan yang lebih kecil atau nantinya pembeli dapat membeli kedelai dengan jumlah yang kecil atau per kilogram. Selanjutnya dari pedagang kecil akan sampai ke level konsumen sebagai penikmat akhir untuk olahan kedelai selain tahu dan tempe, seperti susu kedelai, kedelai goreng, maupun olahan kedelai lainnya.

Hasil panen dari petani akan diantar dan dijual ke pengepul di tiap kawasannya, dimana pengepul sebelum panen raya akan mencari dan mendatangi petani untuk meminta hasil panen kedelai untuk dijual kepadanya. Pada Gambar 4, pengepul hanya akan menjual kedelainya ke KOPTI. Hal ini dikarenakan ada permintaan dari KOPTI terhadap kedelai lokal, dimana saat tidak panen raya kedelai, KOPTI memilih menjual kedelai impor yang harganya lebih murah. Harga kedelai lokal yang jatuh membuat pengepul mempercepat aliran barangnya, sehingga mau menjual ke KOPTI dengan harga yang murah agar ketersediaan kedelai yang disimpan dapat habis sebelum merugi. KOPTI lebih fokus untuk menyediakan kedelai impor untuk produksi tahu tempe sebagai kebutuhan dari konsumen. Apabila ada permintaan untuk kedelai lokal dari konsumen maka KOPTI meminta pasokan dari pengepul, apabila tidak ada permintaan dari konsumen maka tidak ada permintaan ke pengepul. Kedelai dari KOPTI didistribusikan ke industri tahu dan tempe sebagai konsumen akhirnya. KOPTI selalu berusaha memenuhi permintaan dari para anggotanya, yaitu industri 


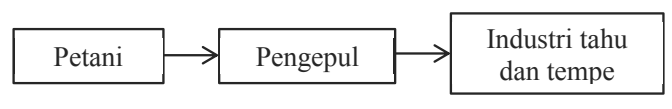

Gambar 5. Skema 4 alur supply chain kedelai

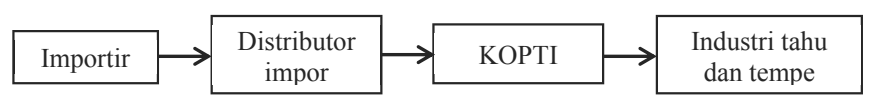

Gambar 6. Skema 5 alur supply chain kedelai

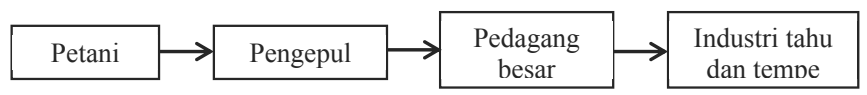

Gambar 7. Skema 6 alur supply chain kedelai

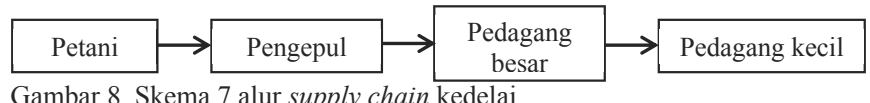

Gambar 8. Skema 7 alur supply chain kedelai

tahu dan tempe di Grobogan baik untuk permintaan kedelai impor maupun lokal.

Pada Gambar 5, hasil produksi dari petani dijual ke pengepul yang berada di sekitar daerah atau kecamatan tersebut dan langsung dijual kepada industri tahu dan tempe tanpa melalui pedagang. Ini terjadi pada industri tahu dan tempe dengan kapasitas produksi yang kecil, yaitu 400-500 $\mathrm{kg}$ kedelai lokal per hari. Tujuannya tentu agar industri mendapatkan harga yang lebih murah jika membeli langsung ke pengepul tanpa melalui pedagang besar yang tentu harganya bisa lebih mahal.

Importir kedelai mendapatkan kedelai dari Amerika Serikat yang nantinya akan masuk melalui pelabuhan di Semarang dan Surabaya. Setelah kedelai impor turun dari kapal, maka akan diambil oleh distributor impor di kota tersebut. Kedelai impor ini biasanya dipesan oleh KOPTI sebagai langganan utamanya, karena KOPTI harus menyediakan kedelai impor untuk kebutuhan produksi industri tahu tempe anggotanya.

Kedelai impor yang sudah dipesan distributor dari importir, akan diambil oleh distributor besar seperti di kota Surabaya ataupun Semarang. Kemudian kedelai impor ini dibeli oleh pedagang besar dengan kuantitas yang cukup besar. Dari pedagang besar ini industri tahu tempe dapat membeli kedelai impor sesuai dengan kebutuhan produksinya. Industri tahu tempe yang membeli di pedagang besar ini biasanya tidak menjadi anggota dari KOPTI sehingga mereka secara individu harus mencari kedelai untuk kebutuhan produksinya.

Kedelai impor dari importir akan diambil oleh distributor impor dan akan didistribusikan ke pedagang besar untuk selanjutnya dibeli oleh pedagang kecil. Pedagang kecil disini adalah pedagang dengan kuantitas penjualan yang lebih besar dari pedagang besar dimana kedelai impor akan dibeli oleh konsumen untuk diolah lebih lanjut.
Tabel 1. Kisaran harga jual dan beli pada setiap tier SC kedelai lokal

\begin{tabular}{llll}
\hline Tier & Kelompok kedelai & $\begin{array}{l}\text { Harga jual } \\
(\mathrm{Rp} / \mathrm{kg})\end{array}$ & $\begin{array}{l}\text { Harga beli } \\
(\mathrm{Rp} / \mathrm{kg})\end{array}$ \\
\hline Petani & Konsumsi & $7.000-7.200$ & - \\
Pengepul & Konsumsi & $7.300-7.400$ & $7.000-7.200$ \\
Pedagang & Konsumsi & $8.000-9.500$ & $7.300-7.400$ \\
Konsumen & Konsumsi & - & $8.000-9.500$ \\
\hline
\end{tabular}

Sumber: Data Primer, 2015

Harga jual di tingkat petani berdasarkan data kuesioner mengenai harga yang diperoleh dari hasil analisa usahatani dengan menghitung struktur ongkos yang disebabkan oleh biaya tanam (baiya produksi), selanjutnya pada tier pengepul harga kedelai dapat dijual dengan harga yang lebih tinggi karena pengepul lebih dominan dalam melakukan kegiatan pemasaran yang dilakukan dengan kelebihan informasi dibanding petani, sehingga biasanya pengepul menjual kedelai dengan pelanggan yang sudah terjaring komunikasinya. Rata-rata perubahan harga jual pada tingkat pengepul dapat mencapai Rp.300,00 dengan kegiatan yang biasa dilakukan yaitu mengeringkan kadar air kedelai terlebih dahulu sebelum dijual. Harga yang sudah sampai ke pedagang akan meningkat lagi sebesar sekitar Rp.700,00 untuk penjualan per kilogramnya. Rentang harga berdasarkan hasil interview dan kisaran umum pada data Kementerian Perdagangan yang menyatakan rentang harga antara Rp.200,00 sampai dengan Rp.500,00 antar tier dalam rantai pasok kedelai.

Saluran distribusi atau saluran pemasaran (SP) kedelai lokal Grobogan terdiri dari 4 skema, yaitu: (1) Saluran Pemasaran 1 (SP I): petani-pengepul-pedagang besarpengrajin tahu tempe, (2) Saluran Pemasaran 2 (SP II): petani-pengepul-pedagang pesar-pedagang kecil, (3) Saluran Pemasaran 3 (SP III): petani-pengepul-KOPTI-pengrajin tahu tempe, dan (4) Saluran Pemasaran 4 (SP IV): petanipengepul-pengrajin tahu tempe

\section{Elastisitas Permintaan Terkait Harga}

Perhitungan elastisitas permintaan diperoleh dari persentase nilai perubahan permintaan dan dibandingkan dengan persentase perubahan harga. Data yang digunakan adalah data dari tahun 2014 sebagai tahun terakhir yang bisa diperoleh dari Dinas Pertanian dan TPH Kabupaten Grobogan. Selanjutnya data-data tersebut dihitung nilai rata-rata untuk setiap tahun serta dianalisis dengan menggunakan software SPSS. Analisis yang dilakukan pada perhitungan elastisitas transmisi harga adalah analisis regresi linear dengan mencari korelasi harga pada tingkat pengecer dengan harga borongan pada produsen (petani). Secara teknis, tujuan dari perhitungan regresi linear yaitu digunakan untuk menguji hubungan, korelasi, pengaruh suatu variabel bebas dan variabel terikat. 
Perhitungan elastisitas transmisi harga termuat pada Persamaan 5.

$\mathrm{Pf}=\mathrm{a}+\mathrm{b} . \mathrm{Pr}$

dengan (Pf) adalah harga di tingkat produsen/petani, (Pr) adalah harga di tingkat pedagang. Melalui persamaan tersebut diharapkan dapat ditemukan korelasi/hubungan terkait harga antara produsen (petani) dan pedagang. Melalui Persamaan 5 dapat dihitung nilai elastisitas transmisi harga (Persamaan 6).

$\mathrm{Et}=1 / \mathrm{b} . \mathrm{Pf} / \mathrm{Pr}$

Dalam perhitungan nilai elastisitas terdapat tier yang menjadi objek perhitungan yaitu pada tier petani dan pedagang. Alasan yang mendasari perhitungan ini adalah karena tier ini merupakan tier yang menjadi awal penjualan terkait harga dari beredarnya kedelai lokal sampai ke ujung saluran pemasaran. Saluran pemasaran kedelai lokal petani selalu menjadi hulu dan pedagang merupakan hilir yang berhadapan langsung dengan konsumen. Pedagang eceran dan pengrajin olahan kedelai memiliki aktivitas tata niaga kedelai yang sering karena pada tier pedagang ini langsung berhubungan dengan konsumen, yaitu bisa dari produsen industri tahu tempe serta konsumen lainnya. Berdasarkan data dari Dinas Pertanian dan TPH Kabupaten Grobogan tahun 2014, harga yang beredar dapat dikelompokkan menjadi dua, yaitu harga borongan dan harga eceran. Harga borongan adalah harga yang beredar di pasaran apabila transaksi yang dilakukan dalam jumlah yang besar seperti pada tingkat petani, pengepul/tengkulak, pedagang besar. Sedangkan harga eceran yaitu harga yang biasa dijual apabila kedelai sudah berada pada pengecer seperti pedagang kecil yang cenderung dekat dengan konsumen akhir. Pengumpulan informasi dilakukan melalui wawancara yang dilakukan pada narasumber pelaku tata niaga kedelai yang melakukan pencatatan pembelian harga dan volume jual-beli. Pencatatan dilakukan dengan cara sederhana dan manual mengenai berapa jumlah kedelai yang terjual dan harga yang disepakati oleh pihak penjual dan pembeli. Adapun informasi mengenai harga tiap-tiap saluran

Tabel 2. Nilai elastisitas harga tiap saluran pemasaran (SP) kedelai di Kabupaten Grobogan

\begin{tabular}{llll}
\hline $\begin{array}{l}\text { Saluran } \\
\text { pemasaran } \\
(\mathrm{SP})\end{array}$ & $\begin{array}{l}\text { Rata-rata harga borongan } \\
\text { tingkat (petani, pengepul, } \\
\text { pedagang besar) }(\mathrm{Pf}) \\
(\mathrm{Rp} / \mathrm{kg})\end{array}$ & $\begin{array}{l}\text { Rata-rata harga } \\
\text { eceran tingkat } \\
\text { pedagang kecil } \\
(\mathrm{Pr})(\mathrm{Rp} / \mathrm{kg})\end{array}$ & $\begin{array}{l}\text { Elastisitas } \\
\text { transmisi } \\
\text { harga }(\mathrm{Et})\end{array}$ \\
\hline SP I & 6.480 & 7.870 & 2.095 \\
SP II & 6.550 & 7.050 & 2.364 \\
SP III & 6.670 & 7.425 & 2.287 \\
SP IV & 7.100 & 7.200 & 2.509 \\
\hline
\end{tabular}

Sumber: Analisis Data Primer, 2016 pemasaran dan hasil elastisitas transmisi harga kedelai lokal Grobogan dapat dilihat pada Tabel 2.

Berdasarkan perhitungan pada Tabel 2 dapat dilihat hasil elastisitas transmisi harga (Et) dengan semua berada pada angka di atas $1(\mathrm{Et}>1)$ atau bersifat elastis, sehingga dapat dikatakan bahwa perubahan harga setiap 1\% di tingkat pedagang (harga jual pedagang $=$ harga beli konsumen) mengakibatkan perubahan lebih besar dari 1\% di tingkat produsen/petani. Berbeda halnya apabila nilai elastisitas yang diperoleh kurang dari 1 yang berarti perubahan harga setiap $1 \%$ di tingkat konsumen (pedagang) akan mengakibatkan perubahan harga sebesar 0,393 (39,3\%) di tingkat produsen (petani). Harga pada pasar petani memiliki keterpaduan secara tidak sempurna dengan harga pada pasar di tingkat pasar konsumen (pedagang) tidak sampai pada petani dalam proporsi yang sebenarnya atau informasi pasar tentang harga tidak sampai ke petani dan pasar tidak bersaing secara sempurna atau dapat dikatakan pasar cenderung bersifat oligopsoni antara lain karena herga penjualan kedelai dipengaruhi oleh konsumen. Laju perubahan harga di tingkat konsumen lebih besar dibandingkan dengan laju perubahan harga di tingkat produsen (petani).

Analisis elatisitas transmisi harga adalah analisis yang menggambarkan sejauh mana dampak perubahan harga suatu barang di satu tingkat pasar terhadap perubahan harga barang tersebut di tempat/tingkat pasar lainnya. Rumus elastisitas transmisi harga terdapat pada Persamaan 7 dan 8).

$\mathrm{Et}=\delta \operatorname{Pr} / \delta \mathrm{Pf} . \operatorname{Pr} / \mathrm{Pf}$

Pr dan Pg berhubungan linear dalam persamaan:

$\operatorname{Pf}=a+b \operatorname{Pr}$

Keterangan:

$\mathrm{Et}=$ elastisitas transmisi harga

$\mathrm{a}=$ intersep

$\mathrm{b}=$ koefisien regresi atau slope

$\mathrm{Pf}=$ harga di tingkat produsen

$\operatorname{Pr}=$ harga di tingkat konsumen

Jika Et $=1$, berarti laju perubahan harga di tingkat konsumen sama dengan laju perubahan harga ditingkat produsen. Hal ini berarti bahwa pasar yang dihadapi oleh seluruh pelaku tataniaga adalah bersaing sempurna, dan sistem tataniaga yang terjadi sudah efisien. Jika Et $<1$, berarti laju perubahan harga di tingkat konsumen lebih kecil dibanding dengan laju perubahan harga di tingkat produsen. Keadaan ini bermakna bahwa pemasaran yang berlaku belum efisien dan pasar yang dihadapi oleh pelaku tataniaga adalah bersaing tidak sempurna, yaitu terdapat kekuatan monopsoni atau oligopoli. Jika Et $>$ 1, maka laju perubahan harga di tingkat produsen. Pasar yang dihadapi oleh seluruh pelaku 
pasar adalah pelaku tidak sempurna, yaitu terdapat kekuatan monopoli dan oligopoli dalam sistem pemasaran tersebut serta sistem pemasaran yang berlaku belum efisien.

Mengingat akan banyaknya hal lain yang dapat mempengaruhi penentuan harga kedelai di Kabupaten Grobogan, dapat dilihat pula ketidakseimbangan antara permintaan dengan penjualan yang terjadi pada tier yang memiliki intensitas tata niaga kedelai yang sering karena berkaitan langsung dengan pasar konsumen, seperti pada tier pedagang yang terlihat pada Gambar 9.

Ketika terjadi kelangkaan di pasaran yang disebabkan oleh produksi di tier petani yang rendah sedangkan permintaan pada tier konsumen yang cenderung konstan dengan mematok pada kuantitas tertentu, hal ini menyebabkan ketidakseimbangan yang terjadi antara kebutuhan dengan penawaran ataupun jumlah ketersediaan kedelai yang siap untuk dijual. Untuk mengantisipasi hal tersebut pedagang biasanya menjual kedelai impor yang memiliki harga yang cenderung lebih murah dan jumlahnya sangat melimpah dibandingkan dengan harga kedelai kuning varietas grobogan. Sedangkan pada tier pengepul dapat dilihat grafik penjualan dan permintaan pada Gambar 10 .

Pada tier pengepul (Gambar 10), dalam kurun waktu tersebut penjualan kedelai yang merupakan wujud dari sejauh mana pemenuhan ketersediaan kedelai masih belum dapat memenuhi permintaan kedelai yang ada. Berdasarkan fakta

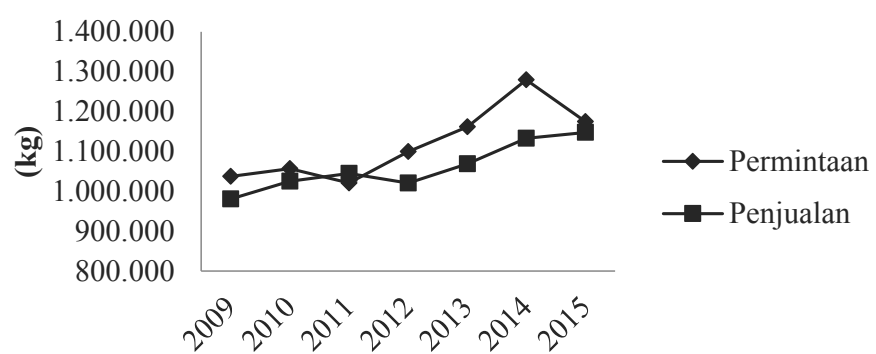

Gambar 9. Grafik permintaan dan penjualan pada tier pedagang

Tabel 3. Konsentrasi rasio pada tier pedagang (besar dan kecil)

\begin{tabular}{llll}
\hline Tahun & Permintaan $(\mathrm{kg})$ & Penjualan $(\mathrm{kg})$ & $\begin{array}{l}\text { Konsentrasi } \\
\text { rasio }\end{array}$ \\
\hline 2010 & $1.056 .503,20$ & $1.025 .287,74$ & 0,9704 \\
2011 & $1.020 .909,68$ & $1.044 .521,70$ & 1,0231 \\
2012 & $1.099 .692,21$ & $1.020 .626,54$ & 0,9281 \\
2013 & $1.161 .452,93$ & $1.069 .065,93$ & 0,9204 \\
2014 & $1.279 .503,33$ & $1.133 .295,67$ & 0,8857 \\
Rata-rata & & & 0,94554
\end{tabular}

Sumber: Analisis Data Primer, 2016
Tabel 4. Konsentrasi rasio pada tier pengepul

\begin{tabular}{llll}
\hline Tahun & Permintaan $(\mathrm{kg})$ & Penjualan $(\mathrm{kg})$ & Konsentrasi rasio \\
\hline 2010 & 55.000 & 48.257 & 0,8774 \\
2011 & 56.714 & 43.315 & 0,7637 \\
2012 & 53.571 & 48.128 & 0,8983 \\
2013 & 60.142 & 48.971 & 0,8142 \\
2014 & 57.857 & 51.892 & 0,8969 \\
Rata-rata & & & 0,8501 \\
\hline
\end{tabular}

Sumber: Analisis Data Primer, 2016

di lapangan, perilaku tier pengepul/tengkulak ini sebetulnya sangat mempengaruhi harga jual kedelai di pasaran Kabupaten Grobogan. Menurut para petani, pengepul/tengkulak ini dapat menentukan harga jual petani maupun harga beli mereka terhadap petani sesuai dengan kondisi fisik kedelai yang dapat diterima dan dilihat oleh pengepul ini, seperti kualitas kedelai, kadar air, berat, dan kriteria-kriteria lain yang biasa digunakan oleh pengepul. Kelebihan peran dari pengepul ini adalah umumnya mereka memiliki tempat penyimpanan kedelai yang cukup besar kapasitasnya, jadi mereka dapat menentukan apakah kedelai akan disimpan terlebih dahulu maupun langsung dijual dengan harga tertentu. Adapun hasil analisa perhitungan terhadap konsentrasi rasio terdapat pada Tabel 3.

Berdasarkan hasil perhitungan terhadap konsentrasi rasio dapat diketahui bahwa pada tier pedagang (besar maupun kecil) memiliki nilai konsentrasi rasio terbesar pada tahun 2011 yaitu sebesar 1,0231. Nilai yang sangat tinggi pada tahun 2011 dikarenakan penjualan yang melebihi permintaan sehingga dapat terpenuhi permintaannya bahkan terjadi kelebihan. Nilai terendah yaitu pada tahun 2014 dengan nilai rasio konsentrasi $(\mathrm{Kr})$ sebesar 0,8857. Adapun secara ratarata dalam kurun waktu lima tahun yaitu pada tahun 2010 sampai dengan 2014 diperoleh nilai konsentrasi rasio ratarata sebesar 0,94554 dan masih dalam angka kurang dari satu $(0,94554<1)$, terdapat gap sebesar 0,05446 atau dengan kata lain tidak dapat memenuhi pasar kedelai sebesar 5,446\%. Hal ini menunjukkan bahwa pada tier pedagang, pasar cenderung bersifat oligopsoni yang artinya hanya ada beberapa pembeli dan memiliki banyak penjual. Pada tier tengkulak/pengepul, juga dilakukan perhitungan terhadap nilai rasio konsentrasi

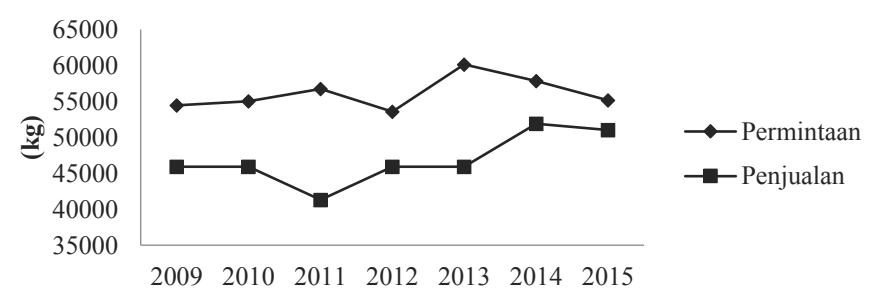

Gambar 10. Grafik permintaan dan penjualan di tier pengepul 
$(\mathrm{Kr})$. Adapun hasil perhitungan nilai rasio konsentrasi pada tier pengepul dapat dilihat pada Tabel 4.

Pada tier pengepul secara rata-rata diperoleh nilai konsentrasi rasio sebesar 0,8501 yang masih bernilai di bawah satu $(0,8501<1)$ artinya terdapat gap dalam pemenuhan permintaan sebanyak 14,99\%. Hal ini juga dapat menunjukkan bahwa pasar cenderung kepada pasar oligopsoni yang artinya hanya ada beberapa pembeli dan banyak penjual seperti halnya pada tier pedagang. Berdasarkan pengamatan yang telah dilakukan baik melalui penelitian ini maupun penelitian terdahulu di Kabupaten Grobogan, harga kedelai untuk kedelai lokal konsumsi rata-rata mencapai Rp.8.000,00 sampai Rp.9.000,00. Adanya range harga ini ditentukan oleh kualitas kedelai yang diperjualbelikan seperti tingkat kadar air apakah sudah sesuai ataupun tidak. Semakin rendah kadar air pada kedelai, maka akan semakin tinggi harga kedelai tersebut.

Nilai elastisitas permintaan terkait harga dapat dihitung pada tahun 2011-2015 berturut-turut sebesar 2,05 pada tahun 2011, pada tahun 2012 sebessar 2,18, pada tahun 2013 sebesar 2,12, pada tahun 2014 sebesar 2,22, pada tahun 2015 sebesar 2,31, dan diramalkan pada tahun 2016 dan 2017 nilai elastisitas permintaan terkait harga akan mengalami penurunan sebesar 2,17 namun tetap bersifat elastis, artinya pada tahun 2016 dan 2017 perubahan 1\% unit satuan harga, menyebabkan perubahan volume permintaan sebesar 2,17 kali lipat.

\section{Analisis Marjin Profik dan Producer Share}

Untuk menghitung jumlah marjin pemasaran yang diperoleh pada masing-masing saluran pemasaran (SP) digunakan (Persamaan 9).

$\mathrm{M}=\mathrm{Hk}-\mathrm{Hp}$

Keterangan:

$\mathrm{M}=$ Marjin pemasaran

$\mathrm{Hk}=$ Harga konsumen

Hp = Harga produsen

Untuk menghitung persentase marjin pemasaran, digunakan Persamaan 10 dari Hanafiah dan Saefudin (2011).

$\% \mathrm{M}=\mathrm{M} / \mathrm{HE}$

Tabel 5. Analisis biaya dan marjin dan keuntungan pemasaran pada pemasaran kedelai di Kabupaten Grobogan

\begin{tabular}{lllllll}
\hline $\begin{array}{l}\text { Saluran } \\
\text { pemasaran } \\
(\mathrm{SP})\end{array}$ & $\begin{array}{l}\text { Biaya } \\
\text { pemasaran } \\
(\mathrm{Rp} / \mathrm{Kg})\end{array}$ & $\begin{array}{l}\text { Biaya } \\
\text { pemasaran } \\
(\%)\end{array}$ & $\begin{array}{l}\text { Marjin } \\
\text { pemasaran } \\
(\mathrm{Rp} / \mathrm{Kg})\end{array}$ & $\begin{array}{l}\text { Marjin } \\
\text { pemasaran } \\
(\%)\end{array}$ & $\begin{array}{l}\text { Keuntungan } \\
\text { pemasaran } \\
(\mathrm{Rp} / \mathrm{kg})\end{array}$ & $\begin{array}{l}\text { Keuntungan } \\
\text { pemasaran } \\
(\%)\end{array}$ \\
\hline SP I & 92,018 & 1,17 & 1.390 & 17,6 & $1.297,98$ & 16,49 \\
SP II & 33,1 & 0,47 & 500 & 7,09 & 466,9 & 6,62 \\
SP III & 74,475 & 1,003 & 751 & 10,11 & 676,525 & 9,11 \\
SP IV & 4,965 & 0,069 & 100 & 1,39 & 95,035 & 1,32 \\
\hline
\end{tabular}

Sumber: Analisis Data Primer, 2016
Keterangan:

$\% \mathrm{M}=$ Persentase marjin

$\mathrm{HE}=$ Harga eceran

$\mathrm{M}=$ Marjin

Sedangkan untuk menghitung farmer share, digunakan Persamaan 11.

$\mathrm{Fs}=\mathrm{Pf} / \mathrm{Pr} \times 100 \%$

Keterangan:

$\mathrm{Fs}=$ Persentase harga yang diterima petani

$\mathrm{Pf}=$ Harga di tingkat petani

$\operatorname{Pr}=$ Harga di tingkat pedagang (pengecer)

Berdasarkan penelitian sebelumnya yang dilakukan oleh Architika (2015) dengan meneliti analisis struktur biaya logistik diperoleh informasi bahwa pada tier petani biaya post-harvest memiliki nilai persentase biaya pemasaran ratarata sebesar $6,62 \%$, pengepul $32,52 \%$, dan pedagang $69,49 \%$ atau dengan kata lain biaya pemasaran pedagang $>$ biaya pemasaran pengepul $>>$ biaya pemasaran petani. Sehingga analisis biaya dan marjin pemasaran (cost margin analysis) kedelai berdasarkan saluran pemasaran kedelai dapat dihitung dan diperoleh hasil pada Tabel 5.

Hasil perhitungan pada Tabel 5 dapat didukung dengan analisis terhadap farmer share pada tingkat petani yang menggambarkan keterserapan harga pada petani sebagai produsen utama kedelai. Adapun hasil analisis perhitungan farmer share dapat dilihat pada Tabel 6.

Berdasarkan informasi pada tabel hasil perhitungan persentase keuntungan pemasaran diperoleh hasil berupa nilai persentase tertinggi pada saluran pemasaran 1 dengan nilai $16,49 \%$, dilanjutkan pada saluran pemasaran 3 dengan nilai $9,11 \%$, saluran pemasaran 2 dengan nilai $6,62 \%$, serta nilai terendah nilai persentase keuntungan pemasaran yaitupada saluran pemasaran ke 4 dengan nilai 1,32\%. Hal yang menjadi perhatian adalah pada saluran pemasaran 4 yang memilki nilai elastisitas transmisi harga yang tertinggi, justru memiliki nilai persentase keuntungan pemasaran terendah.

Dari Tabel 6 juga dapat dilihat bahwa saluran pemasaran IV memiliki nilai farmer share tertinggi dibandingkan dengan lainnya, karena pada saluran pemasaran ini merupakan saluran terpendek dan petani lebih bisa dapat berhubungan langsung dengan konsumen, selain itu juga peran pengepul pada saluran pemasaran ini lebih dapat terkendali dalam menentukan harga sehingga lebih efisien. Dapat dianalisa dan ditarik hubungan bahwa dalam kondisi di lapangan nilai persentase keuntungan pemasaran yang kecil, namun nilai elastisitas transmisi harga, dan farmer share yang besar dapat disebabkan oleh aktivitas pemasaran tier petani pada saluran pemasaran 4 yang tidak sesering pada saluran pemasaran lainnya, karena pada saluran pemasaran tersebut adalah saluran pemasaran dengan rantai terpendek, dan petani dapat langsung menjual tanpa melewati tier sebanyak saluran pemasaran lainnya. 
Tabel 6. Marjin pemasaran dan farmer share pada saluran pemasaran kedelai

\begin{tabular}{llll}
\hline $\begin{array}{l}\text { Saluran } \\
\text { pemasaran (SP) }\end{array}$ & $\begin{array}{l}\text { Marjin pemasaran } \\
(\mathrm{Rp} / \mathrm{Kg})\end{array}$ & $\begin{array}{l}\text { Persentase marjin } \\
\text { pemasaran }(\%)\end{array}$ & $\begin{array}{l}\text { Farmer } \\
\text { share }(\%)\end{array}$ \\
\hline SP I & 1.390 & 17,6 & 82,33 \\
SP II & 500 & 7,09 & 92,90 \\
SP III & 1.125 & 10,11 & 89,88 \\
SP IV & 100 & 1,39 & 98,61 \\
\hline
\end{tabular}

Sumber: Analisis Data Primer, 2016

Semua kegiatan ekonomi, tidak terkecuali pemasaran, juga menghendaki adanya efisiensi. Sistem pemasaran dianggap efisien apabila memenuhi dua syarat, yaitu mampu menyampaikan hasil-hasil dari petani produsen kepada konsumen dengan biaya serendah mungkin dan mampu mengadakan pembagian yang adil dari keseluruhan harga yang dibayar konsumen akhir kepada semua pihak yang telah ikut serta di dalam kegiatan produksi dan kegiatan pemasaran komoditas tersebut. Sehingga dapat dikatakan bahwa saluran pemasaran yang paling efektif adalah saluran pemasaran 4 yang terdiri dari petani ke kelompok tani dan dilanjutkan ke pengrajin tahu/tempe.

Harga jual yang rendah di tingkat petani menyebabkan kurang kompetitif dibandingkan komoditas palawija yang lainnya. Hal ini menjadi salah satu faktor utama yang menyebabkan petani kurang berminat membudidayakan kedelai. Peningkatan harga jual kedelai di tingkat petani merupakan salah satu faktor utama dalam mengembalikan minat petani untuk menanam kedelai. Harga jual kedelai di tingkat petani pada tahun 2012 berkisar antara Rp.7.300Rp.7.700/kg, sedangkan harga kedelai di tingkat konsumen berkisar antara Rp.10.000-Rp.10.600/kg (Pusat Data dan Informasi Pertanian, 2013). Terjadi marjin yang cukup besar di tingkat konsumen yang tidak dapat dinikmati oleh produsen. Peran Bulog sangat dibutuhkan dalam mengatur regulasi harga dan distribusi kedelai baik secara regional maupun nasional mengingat seringkali terjadi kelangkaan pada kasus tata niaga kedelai. Penetapan floor price dan ceiling price pada prinsipnya tidak merugikan petani dan konsumen (produsen tahu dan tempe). Harga yang ditetapkan ini dapat memotivasi petani dalam membudidayakan kedelai secara intensif sehingga dapat meningkatkan produktivitas dan produksi kedelai, sehingga dapat memenuhi permintaan.

\section{KESIMPULAN}

Dari penelitian yang telah dilakukan, dapat ditarik kesimpulan bahwa nilai elastisitas harga (Et) kedelai diperoleh nilai Et lebih dari 1 pada semua saluran pemasaran kedelai di wilayah Grobogan yaitu pada saluran pemasaran $1(2,095)$, saluran pemasaran $2(2,364)$, saluran pemasaran
3 (2,287), dan nilai tertinggi yaitu pada saluran pemasaran 4 dengan nilai Et sebesar 2,509, yang berarti barang akan cepat tersalurkan ke konsumen, sehingga mengurangi risiko rusak, dan segera dikonsumsi oleh konsumen untuk diolah menjadi bahan pangan lain. Saluran pemasaran yang paling efisien dengan permintaan yang paling efektif adalah saluran pemasaran 4 dengan susunan jalur rantai pasok: Petani ke kelompok tani dan dilanjutkan ke pengrajin tahu dan tempe. Kontribusi kelompok tani, dalam hal ini KOPTI perlu lebih ditingkatkan dalam pemenuhan ketersediaan kedelai lokal untuk memenuhi kebutuhan pengrajin tahu dan tempe.

\section{UCAPAN TERIMA KASIH}

Terima kasih kami sampaikan kepada Fakultas Teknologi Pertanian UGM yang telah mendukung dana penelitian dalam Hibah Penelitian RKAT Tahun 2016 dan dukungan dari Farida Rahmawati dan Erna Purwaningsih yang telah mendukung dalam pengambilan data penelitian.

\section{DAFTAR PUSTAKA}

Architika, F.T. (2015). Analisis Bullwhip Effect dalam Supply Chain Management pada Komoditas Kedelai [Glycine $\operatorname{Max}(L)]$. Skripsi. Fakultas Teknologi Pertanian. Universitas Gadjah Mada. Yogyakarta, Indonesia.

Badan Pusat Statistik (2014). Statistik Pertanian Indonesia. Biro Pusat Statistik. Jawa Tengah.

Bappebti. (2014). Analisis Monitoring Perkembangan Harga Bahan Pangan Pokok. Kementerian Perdagangan. Jakarta, Indonesia.

Fibich, G., Gavious, A. dan Lowengart, O. (2005). The dynamics of price elasticity of demand in the presence of reference price effects. Tel Aviv University and Ben Gurion University.

Femenia, F. dan Gohin, A. (2011). Dynamic modelling of agricultural policies the role of expectation scheme. Journal Economic Modelling 28: 1950-1958.

Hanafiah dan Saefuddin (2011). Tata Niaga Hasil Perikanan. Jakarta: Universitas Indonesia.

Kristanti, N.E. dan Guritno, A.D. (2016). The dynamic model of soybean (Glycine $\max$ (L.) Merr.) in Indonesia: A supply chain perspective. Scientific Times Journal of Agriculture. http://scientifitimes.org/journals/ Agriculture/articlesinpress.php-online.

Nurhayati, W. (2014). Sensus BPS: Petani Tak Tertarik Tanam Kedelai. Detik Finance. http://finance.detik.com/read/2 
014/12/23/145600/2785629/4/sensus-bps-petani-taktertarik-tanam-kedelai. [2 Desember 2015].

Petroff, J. (2002). Course Elastisitas Penawaran dan Permintaan Harga. http:/www.peoi.org/Courses/ Coursesba/mic/mic2.html.

Pusat Data dan Sistem Informasi Pertanian (2014). Ekspor Impor Komoditas Pertanian. Pusdatin Volume 6 No 1.

Soemodihardjo, dan Haryanto, I. (1997). Dasar-dasar Determinasi Harga Produk Produk Pertanian. Fakultas Pertanian. Universitas Jember. Jember, Jawa Timur.
Simatupang dan Mangihut, T. (1995). Teori Sistem Suatu Perspektif Teknik Industri. Andi Offset. Yogyakarta.

Turocy, L., Theodore dan Benhard, S. (2001). Game Theory. CDAM Research Report LSE-CDAM. London School of Economics.

Wijaya, F. (1997). Seri Pengantar Ekonomika, Ekonomika mikro Edisi Kedua. BPFE. Yogyakarta. 